DOI: https://doi.org/10.24113/ijellh.v8i1.10400

\title{
Exploring Pre-Service EFL Teachers' Perceptions of Assessment in Beninese Secondary Schools
}

\author{
Jean-Marc Gnonlonfoun \\ GRI-DiGeST/LARPET/ENSET/UNSTIM-A \\ Cotonou, Bénin \\ vostook07@gmail.com
}

\begin{abstract}
There are limited resources available as far as pre-service EFL teachers' views regarding assessment are concerned. Therefore, this study is set out to explore Beninese pre-service EFL teachers' perspectives on the issue. In this line, 120 pre-service teachers were randomly selected from the $18^{\text {th }}$ promotion of the BAPES/CAPES programme at the Teacher Training School of Porto-Novo (Ecole Normale Supérieure de Porto-Novo). The semi-structured interviews conducted with groups of ten participants were recorded and transcribed using Voice Notes 3.56 (free) set on a TECNO-W3 android cellphone. The data collected demonstrated that there is a gap between assessment theories and practices. Therefore, there is a necessity for all actors involved to work in order to redress the value accorded to assessment and the inherent grades in the Beninese society.
\end{abstract}

Keywords: Benin, Pre-service EFL Teachers, Perceptions, Assessment. 


\section{DOI: https://doi.org/10.24113/ijellh.v8i1.10400}

\section{Problem and Purpose}

Whatever the subject being taught, it is important to assess the level reached in order to obtain valuable data that would shed light on the process, the actors involved as well as the difficulties and merits of the activities. As such, modern foreign languages and their teaching and learning are no exception. Indeed, in classrooms, one of the core activities that language teachers often carry out is the assessment of their learners (Addamigh, 2006; Chen, 2003; Wishon, Crabtree and Jones, 1998).

Based on the temptative definition provided above, it appears that teachers, as assessors, exercise a power caught up in an array of issues about themselves (the testers and raters) and their learners (who are the testees). And this opens up the way to sharp criticisms related to subjectivity, individual problems, test-related biases, etc. Different actors' voices, roles and beliefs step in. Indeed, issues of assessment design and implementation (Bauch, 1984; Al-sharafi, 1998; Black and Wiliam, 1998; Aliakbari, 2004; Al-Busaidi, 2007) have gained increased attention in education. Moreover, the teaching of English language in different countries has contributed to robust discussions on EFL teachers' English language assessment. However, language teachers and more specifically pre-service EFL teachers' beliefs about assessment have remained unexplored.

Considering the strategic influence of assessment and its results in the educational settings and the influence of teachers' beliefs on language learning and motivation in language learning, there is a need for research. Indeed, while there is sufficient literature available on strategies to reduce anxiety and to increase motivation to learn among students, 


\section{DOI: https://doi.org/10.24113/ijellh.v8i1.10400}

there is a dearth of data on assessment as viewed by modern language teachers and especially pre-service EFL teachers.

That is why the aim of the present study, therefore, is to investigate the perspectives of pre-service teachers on assessment in their class. Indeed, it is important to assess their views early in the pre-service program so that appropriate measures can be taken to redress the situation before they are put in charge of classes. As such, the results of the present study will contribute to advance research in these areas so that teacher educators are better able to equip their trainees with adequate theoretical and practical knowledge.

\section{Methodology}

In Gnonlonfoun (2014:99), it can be read that researchers often have basically to choose between two research designs: the quantitative research methods and the qualitative research methods. To carry out this study, the descriptive and qualitative approach has been used. As such, 120 pre-service EFL teachers were chosen randomly from the 220 officially registered for the $18^{\text {th }}$ promotion. Care has been taken to select participants coming from each of the 12 regions in Benin. This is for representation purposes. A semi-structured interview has been organized per groups of 10 participants each so as to get their personal beliefs about EFL assessment in Beninese secondary schools and their opinion about the current assessment practices in their school.

Interviews were recorded and automatically transcribed using Voice Notes ${ }^{\mathrm{TM}}$ v.3.56 (free) set up on hiOS android TECNO-W3 cellphone. Transcripts were proofread and cross-sectional analysis was carried out to sort key excerpts for interpretation. 


\section{DOI: https://doi.org/10.24113/ijellh.v8i1.10400}

\section{Findings}

Societal beliefs refer to the impact of assessment on teaching, on learning, and on both teachers' and students' accountability. In Viviane's view, assessment is only a reference point to establish students' level of achievement. Kofie further added that

Society considers assessment as marks or grades. It is difficult to assess students in secondary school, because only marks are important, so if a student gets a good grade, everyone suppose that this student is eligible to enter university.

Therefore, society considers assessment as a tool to communicate with students and their parents. Gérard said that "I rarely care about the marks that I give to my students. But students and their families always need to see the results and it is important to them". Solange believed in the importance of assessment as an instrument for recognizing students' learning needs. In that line, she said:

I think assessment is a useful tool to see if students need more support in their learning. Maybe some students need more help and they cannot accomplish tasks on their own. So, the role of formative assessment is very important.

Some other teachers believed that assessment is not useful. A good illustration is Dossou who indicates that: "assessment is not useful; teachers should only focus on their teaching." Biowa was clearer: "Assessment is only good for students to study hard because they fear of getting bad grades. Nothing else." As can be seen in the previous statements, 


\section{DOI: https://doi.org/10.24113/ijellh.v8i1.10400}

these teachers believed that assessment is not a part of their teaching duties. They perceived that the only usefulness of assessment relies on extrinsically motivating learners and make them study hard. She mentioned that "it is important for families and students themselves to receive grades and see the results, but for me it is useless." This teacher believed that assessment is only a tool to communicate with parents who are interested in final grades only.

\section{Discussion}

The data collected and interpreted evidence the complexity of assessment. Most of the teachers involved in this study believed that the use made of test results are highly questionable in that they are not often used by teachers, school administrations and parents to help students improve their learning. Therefore, as Atkinson (2012) indicates, such an issue is a challenge to teacher education and raises the necessity of research to support teachers in dealing with assessment data in ways that fosters their own learning and growth as well as that of their students. Teachers believed that assessment should monitor and improve learning otherwise it would be useless. As Shohamy (2001) states, teachers' attention and concern should be about the quality of the pupils' performance.

Teacher participants are therefore truly knowledgeable in their students' learning. This knowledge and experience make the learning environment more conducive for teaching and learning. Responses from participants tend to indicate that they did not have an efficient role in the assessment process. For them, the value given to assessment and the inherent grades in the Beninese society is to be revised. Therefore, they seem to be aware that classroom grades do not truly reflect the actual value of the learner or even the learner's capacities and skills. And as such, the data from this study support the results of previous 
DOI: $\underline{\text { https://doi.org/10.24113/ijellh.v8i1.10400 }}$

studies (Brown et al., 2011; Remesal, 2011 and Yin, 2010) which showed that teachers hold various beliefs that affect their teaching and assessment practices. As a consequence, teachers' beliefs and roles are a key in improving classroom assessment practices.

\section{Conclusion}

The results of the present study revealed teachers' perspectives on the societal beliefs and expectations from students' assessments and indicated that there is a gap between teachers' assessment beliefs and their practices. 


\section{DOI: $\underline{\text { https://doi.org/10.24113/ijellh.v8i1.10400 }}$}

Bibliography

Addamigh, K. (2006). Construct validity of foreign language tests. In C. Coombe, P. Davidson, \& D. Lloyd (Eds.), Proceedings of the 7th \& 8th Current Trends in English Language Testing Conference (pp. 55-72). Dubai: TESOL Arabia Publications.

Al-Busaidi, S. (2007). Assessing the active and passive vocabulary knowledge of EFL students in the Sultanate of Oman. In A. Jendli, S. Troudi, \& C. Coombe (Eds.), The power of language: Perspectives from Arabia (pp. 114-127). Dubai: TESOL Arabia Publications.

Al-Hamly, M., \& Coombe, C. (2005). To change or not to change: Investigating the value of MCQ answer changing for Gulf Arab students. Language Testing, 22 , 509-531.

Aliakbari, M. (2004): The Issue of Culture in the Iranian ELT Context. Ph.D. Dissertation, English Department: Isfahan University.

Al-sharafi, A. (1998). An investigation of the beliefs and practice of foreign language teachers: A case study of five American high school foreign language teachers in Leon County. Unpublished doctoral dissertation. College of Education of Florida State University.

Atkinson, B. M. (2012). Target practice: Reader response theory and teachers`interpretations of students`SAT 10 scores in data based professional development. Journal of Teacher Education, 63(3), 201-213.

Bauch, P. (1984). The impact of teacherse instructional beliefs on their teaching: Implications for research and practice. ERIC Digest. ED252954.

Black, P., \& Wiliam, D. (1998). Inside the black box: Raising standards through classroom assessment. Phi Delta Kappan, 80, 139-148. 
DOI: $\underline{\text { https://doi.org/10.24113/ijellh.v8i1.10400 }}$

Borg, S. (1999). Teachers ${ }^{\mathrm{ee}}$ theories in grammar teaching. ELT Journal, 53(3), 157-167.

Brookhart, S. (2011). Educational Assessment Knowledge and Skills for Teachers. Educational Measurement: Issues and Practice, 30, 3-12.

Brown, G. T. L. (2008). Conceptions of assessment: Understanding what assessment means to teachers and students. New York, NY: Nova Science Publishers.

Brown, G. T. L., Harris, L. R., \& Harnett, J. A. (2010). Teachers' conceptions of feedback: Results from a national sample of New Zealand teachers. Paper presented at the International Testing Commission 7th Biannual Conference, Hong Kong.

Brown, G. T. L., Hui, S. K. F., Yu, F. W. M., \& Kennedy, K. J. (2011). Teachers` conceptions of assessment in Chinese context: A tripartite model of accountability, improvement, and irrelevance. International Journal of Educational Research, 50, 307- 320 .

Chen, H. (2003). A study of primary school English teachers' beliefs and practices in multiple assessments: A case study in Taipei City. Unpublished master theses. Taipei: National Taipei Teachers College.

Gnonlonfoun, J.M. (2014), Exploring Secondary School EFL Teachers' attitudes to and Perceptions of Using the Internet in English Language Teaching in Benin. Doctoral Dissertation, Abomey-Calavi: Doctoral School of the Arts Faculty.

Remesal, A. (2011). Primary and secondary teachers ${ }^{\text {ee }}$ conceptions of assessment: A qualitative study. Teaching and teacher education, 27, 472-482.

Shohamy, E. (2000). The relationship between language testing and second language acquisition revisited. System, 28(4), 541-553. 
DOI: $\underline{\text { https://doi.org/10.24113/ijellh.v8i1.10400 }}$

Wishon, P., Crabtree, K., \& Jones, M. (1998). Curriculum for the primary years: An integrative approach. Upper Saddle River, NJ: Merrill, An Imprint of Prentice Hall.

Yin, M. (2010). Understanding classroom language assessment through teacher thinking research. Language Assessment Quarterly, 7(2), 175-194. 